\title{
Flavor and Other Quality Factors of Enzyme-peeled Oranges Treated with Citric Acid
}

\author{
Simona Pinnavaia and Emilio Senesi \\ Istituto Sperimentale per la Valorizzazione Tecnologica dei Prodotti Agricoli \\ (IVTPA), Via Venezian 26, Milano, Italy
}

\author{
Anne Plotto ${ }^{1}$, Jan A. Narciso, and Elizabeth A. Baldwin \\ USDA-ARS Citrus \& Subtropical Products Laboratory, 600 Avenue S, NW, \\ Winter Haven, FL 33881
}

Additional index words. Citrus sinensis, fresh cut, orange, enzyme peeling, volatiles

\begin{abstract}
Oranges can be satisfactorily processed for fresh slices using a process of enzyme infiltration under vacuum. Scored 'Valencia' and 'Hamlin' oranges were placed under $90 \mathrm{kPa}$ vacuum in water, $1 \%$ citric acid (CA), or $1000 \mathrm{ppm}$ pectinase (Ultrazym) at $30{ }^{\circ} \mathrm{C}$ for $2 \mathrm{~min}$ followed by $30 \mathrm{~min}$ incubation in air. After peeling, fruit were washed, cut, and all but CA-infused slices were dipped in water or $1 \% \mathrm{CA}$ for $2 \mathrm{~min}$. Drained slices were placed in sealed $454-\mathrm{mL}$ deli containers and stored at $5^{\circ} \mathrm{C}$ for up to 21 days. All 'Valencia' slices had microbial counts less than $1.0 \log \mathrm{cfu} \cdot \mathrm{g}^{-1}(\mathrm{cfu}=$ colony-forming units) after 7 days storage, and slices from CA-infused fruit had less than $1.0 \log \mathrm{cfu} \cdot \mathrm{g}^{-1}$ after 21 days storage. For 'Hamlin', CA dips controlled bacterial growth on slices from water-infused oranges, except at 14 days. Enzyme-infused oranges resulted in slices with lower counts for both cultivars. CA-treated sliced (post enzyme treatment or by infusion) oranges had higher titratable acidity initially ('Hamlin') and after 14 days ('Valencia'). When presented to a taste panel, 'Valencia' slices from enzyme-peeled fruit were preferred for texture after 2 days and 8 days in storage. In contrast, slices from fruit infused with water or citric acid were least preferred, were firmer, and had thicker segment membranes. Appearance of enzyme-treated fruit was preferred for 'Hamlin' oranges. Enzyme treatments increased levels of aroma volatiles, methanol and methyl butanoate, in 'Hamlin' slices, but overall sensory flavor data were unaffected.
\end{abstract}

Citrus fruit, particularly oranges, are traditionally known to be high in vitamin $\mathrm{C}$ and are now promoted as healthy and rich in antioxidants (Florida Department of Citrus, 2006). However, because the peel must be removed for consumption, this fruit is not as easy to eat as other fruits such as apples, in which the peel is ingested. The need for convenience and ready-to-eat food has driven the fast growth of the fresh-cut produce industry (Hodge, 2003). In the first quarter of 2006 , fresh-cut fruit was the area with the highest growth (15.7\% from 2005) with sales generating \$242 million and representing $19 \%$ of the total fresh-cut sales, an increase of $6.5 \%$ over the same quarter in 2005 (Warren, 2006). With such a strong growth,

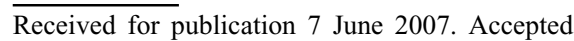
for publication 5 July 2007.

Mention of a trademark or proprietary product is for identification only and does not imply a guarantee or warranty of the product by the U.S. Department of Agriculture. The U.S. Department of Agriculture prohibits discrimination in all its programs and activities on the basis of race, color, national origin, gender, religion, age, disability, political beliefs, sexual orientation, and marital or family status.

${ }^{1}$ To whom reprint requests should be addressed; e-mail plotto@citrus.usda.gov.
}

there is a genuine motivation for diversifying fresh-cut products sold on the market, still dominated by muskmelons, pineapples, apples, and grapes (Cooperhouse, 2003). Despite that need, ready-to-eat oranges are still difficult to find commercially. The relatively low respiration rate and the high acidity of citrus fruit should make oranges a stable product suitable for the fresh-cut market (Abeles, 1973; Rocha et al., 1995).

Commercialization of fresh-cut oranges is limited mostly by technical difficulties in peeling as a result of the peculiarity of citrus peel (presence of albedo) and pulp (vesicle structure). The use of mechanical peelers with blades is not as efficient as for other fruit such as kiwifruits and apples, because it is not possible to completely remove the peel from the citrus segments without damaging the segment surface, losing edible material and generating juice leakage (Senesi et al., 2005). In the late 1970s, a method to peel citrus by placing scored fruit in an enzymatic solution under vacuum was developed (Bruemmer, 1981). The enzyme, pectinase or cellulase, digested the albedo, facilitating peel removal (Baker and Bruemmer, 1989; Bruemmer, 1981; Ismail et al., 2005; Pretel et al., 1997). Unfortunately, juice leakage, loss of texture, and off flavors caused by enzyme activity during storage were reported (Baker and Bruemmer, 1989; Baker and
Hagenmaier, 1995; Ismail et al., 2005; Senesi et al., 2003). Therefore, further studies compared vacuum and high-pressure infusion in the presence or absence of enzymes, determining that water infiltration alone could also result in easy peeling of oranges with significantly less juice leakage and firmness loss during storage (Pao et al., 1996a, 1996b, 1997; Pinnavaia et al., unpublished data), but resulting in residual albedo tissue, which affected appearance (Pinnavaia et al., 2006).

In addition to residual enzymatic activity on fresh-cut slices in storage, microbial stability is also a concern for fresh-cut products in general (Zhuang et al., 2003), but especially for citrus processed through infusion of water or enzyme solutions (Pinnavaia et al., 2006) because this could be a source of contamination. Maintaining a low $\mathrm{pH}$ on food surfaces can often extend storage by creating a hostile environment for nonacid-tolerant organisms (Hobbs, 1986). Pao and Petracek (1997) were able to extend shelf life of peeled and cut oranges with $0.5 \%$ and $1 \%$ citric acid when fruit were stored at $4{ }^{\circ} \mathrm{C}$ and $21{ }^{\circ} \mathrm{C}$, respectively. In that study, oranges were vacuum-peeled with water, but no enzyme was used.

An earlier study optimized the process conditions for enzyme-peeling of 'Valencia' oranges using two commercial pectinase products (Pinnavaia et al., 2006). The pectinase eased peeling of 'Valencia' oranges, which are normally characterized by a strong adherence of albedo tissue to the fruit segments after peel removal. The use of 1000 ppm pectinase, a low level compared with earlier studies (Ismail et al., 2005; Pretel et al., 1997), did not result in significant juice leakage after 2 weeks storage (less than 3.6\% of the initial weight). Therefore, the main focus in this study was to compare fresh slices from 'Valencia' and 'Hamlin' oranges infused under vacuum with solutions of water, enzyme, or citric acid along with a postcutting treatment in the form of a citric acid dip for effect on shelf life, microbial stability, and quality.

\section{Materials and Methods}

Fruit material. 'Valencia' and 'Hamlin' oranges (Citrus sinensis L.) were obtained from a commercial grower in Haines City, FL, in June and Dec. 2005, respectively. Fruit were brought back to the laboratory and stored at $7{ }^{\circ} \mathrm{C}$ for 4 to $14 \mathrm{~d}$ before processing.

Processing. Before processing, each fruit was carefully cleaned with an abrasive pad and hot water and then sanitized with peroxyacetic acid (PAA) (StorOx ${ }^{\circledR}$; BioSafe Systems, Glastonbury, CT) by dipping fruit in a $100 \mathrm{ppm}$ PAA solution at $35^{\circ} \mathrm{C}$ for $3 \mathrm{~min}$ (Narciso and Plotto, 2005). All handling surfaces and equipment were sanitized with a chlorine solution at $400 \mathrm{ppm}$ or ethanol at $75 \%$ and, whenever possible (knives and foil sheets), sterilized in an autoclave. Fruit were always handled with gloved hands.

The peel was scored by hand with a citrus peeler (Sunkist Citrus Peeler ${ }^{\mathrm{TM}}$, Santa Ana, 
CA) making six cuts from stem to blossom end to permit infusion of treatment solutions into the albedo. Scored fruit were kept submerged with weights in three different solutions prepared with double deionized water at room temperature: 1) water; 2) $0.1 \%$ pectinase (Ultrazym 100G; Novozymes, Dittingen, Switzerland); and 3) 1\% citric acid (CA) (Aldrich Chemical Company, Milwaukee, WI), and placed in a vacuum chamber. Oranges were infused by evacuating the chamber to $\approx 90 \mathrm{kPa}(\approx 675$ $\mathrm{mm} \mathrm{Hg}$ ) holding the vacuum for 2 min and then slowly releasing it over a 3-min interval. Water-infused oranges were immediately peeled by hand, whereas enzyme-infused fruit were left to incubate an additional 30 min in air at room temperature and then peeled. Peeled oranges from both treatments were rinsed individually with running deionized water and gently rubbed to wash any residual enzyme (when used) and to remove excess albedo. Fruit from CA infusion were peeled immediately after infusion without an additional rinse.

Peeled oranges were cut radially into six sections using a sharp knife (Pao et al., 1997). Both slices from water- and enzyme-infused fruit were dipped into a $1 \% \mathrm{CA}$ solution or sterilized water (control) for $\approx 2 \mathrm{~min}$ and then drained in colanders. Fruit from CA infusion were cut without further dip. Slices from all treatments were placed in $453.6-\mathrm{mL}$ (16 oz.) plastic containers with tightly closed lids (deli/food containers; Sweetheart Cup Company, Owings Mills, MD) and stored at $5{ }^{\circ} \mathrm{C}$ for up to $21 \mathrm{~d}$. Four or five slices were placed in each container with three replicate containers per treatment.

Orange slices were evaluated weekly for firmness, titratable acidity (TA), $\mathrm{pH}$, soluble solids content (SSC), volatiles (only 'Hamlin'), microbial population, texture, appearance (only 'Hamlin'), and flavor.

Microbial assays. For each replication, three representative slices were taken from each container and placed in sterile $950-\mathrm{mL}$ sampling bags (Fisherbrand; Fisher Scientific, Pittsburgh, PA). After weighing, $99 \mathrm{~mL}$ of sterile phosphate buffer $(\mathrm{pH}$ 7.2) was added to the bags and samples were gently massaged by hand for $2 \mathrm{~min}$ to disperse all microorganisms present on the fruit slice surface into the buffer. Small aliquots $(\approx 5$ $\mathrm{mL}$ ) of buffer were then taken from each bag and plated using a Whitley Automatic Spiral Plater (DW Scientific, Ltd., Shipley, West Yorkshire, UK) onto potato dextrose agar (PDA), orange serum agar (OSA), and plate count agar (PCA) (BD/Difco Brand, Sparks, $\mathrm{MD})$. The different media were chosen to isolate a broad range of organisms (PCA for bacteria, OSA for microorganisms of citrus products, PDA for yeasts and molds). The plates were incubated at $35^{\circ} \mathrm{C}$ for $48 \mathrm{~h}$ and then left for 2 to $3 \mathrm{~d}$ at room temperature ( 25 $\left.{ }^{\circ} \mathrm{C}\right)$. The results were read with a ProtoCOL colony counter (Synoptics, Ltd., Cambridge, UK). Colony counts for replicate plates were averaged and results were reported as $\log$ $\mathrm{cfu} \cdot \mathrm{g}^{-1}$ (cfu = colony-forming units).

\section{Quality parameters}

Firmness. Firmness was tested on orange slices using a XT2 Texture Analyzer (Stable Micro Systems, Surrey, UK) equipped with a 25-kg load cell and a 5-cm diameter flat probe (Baker and Bruemmer, 1989; Ismail et al., 2005). Tests were carried out with a stroke speed of $2 \mathrm{~mm} \cdot \mathrm{sec}^{-1}$

Table 1. Microbial populations ( $\left.\log \mathrm{cfu} \cdot \mathrm{g}^{-1}\right)$ for 'Hamlin' and 'Valencia' fresh cut slices stored $21 \mathrm{~d}$ at $5{ }^{\circ} \mathrm{C}$.

\begin{tabular}{lcccc}
\hline & \multicolumn{4}{c}{ Days in storage } \\
\cline { 2 - 5 } & \multicolumn{1}{c}{1} & \multicolumn{1}{c}{14} & 21 \\
\hline CIT & $<1.0 \mathrm{a} \mathrm{A}$ & $<1.0 \mathrm{a} \mathrm{A}$ & $<1.0 \mathrm{~b} \mathrm{~A}$ & $<1.0 \mathrm{~d} \mathrm{~A}$ \\
EW & $<1.0 \mathrm{a} \mathrm{B}$ & $<1.0 \mathrm{a} \mathrm{B}$ & $<1.0 \mathrm{~b} \mathrm{~B}$ & $2.13 \mathrm{~cd} \mathrm{~A}$ \\
EC & $<1.0 \mathrm{a} \mathrm{B}$ & $<1.0 \mathrm{a} \mathrm{B}$ & $<1.0 \mathrm{~b} \mathrm{~B}$ & $4.71 \mathrm{~b} \mathrm{~A}$ \\
WW & $<1.0 \mathrm{a} \mathrm{B}$ & $<1.0 \mathrm{a} \mathrm{B}$ & $4.40 \mathrm{a} \mathrm{A}$ & $2.68 \mathrm{a} \mathrm{A}$ \\
WC & $<1.0 \mathrm{a} \mathrm{B}$ & $<1.0 \mathrm{a} \mathrm{B}$ & $2.75 \mathrm{a} \mathrm{A}$ & $2.73 \mathrm{bc} \mathrm{A}$ \\
& & & & \\
CIT & $<1.0 \mathrm{~b} \mathrm{~A}$ & $1.09 \mathrm{~b} \mathrm{~A}$ & $<1.0 \mathrm{~b} \mathrm{~A}$ & $1.24 \mathrm{~b} \mathrm{~A}$ \\
EW & $2.34 \mathrm{a} \mathrm{A}$ & $1.89 \mathrm{~b} \mathrm{~B}$ & $2.08 \mathrm{ab} \mathrm{B}$ & $1.00 \mathrm{~b} \mathrm{~B}$ \\
EC & $<1.0 \mathrm{~b} \mathrm{~A}$ & $1.36 \mathrm{~b} \mathrm{~A}$ & $0.80 \mathrm{~b} \mathrm{~A}$ & $1.40 \mathrm{~b} \mathrm{~A}$ \\
WW & $2.50 \mathrm{a} \mathrm{A}$ & $2.40 \mathrm{a} \mathrm{A}$ & $2.46 \mathrm{ab} \mathrm{A}$ & $3.19 \mathrm{a} \mathrm{A}$ \\
WC & $<1.0 \mathrm{~b} \mathrm{~B}$ & $<1.0 \mathrm{~b} \mathrm{~B}$ & $3.13 \mathrm{a} \mathrm{A}$ & $<1.0 \mathrm{~b} \mathrm{~B}$ \\
\hline
\end{tabular}

${ }^{2}$ Means followed with the same letter are not significantly different by the Kruskal-Wallis test (significance at $5 \%$ ): between treatments within a storage day (lower case letters) and within treatment across storage (upper case letters). Multiple pairwise comparisons were done using the Dunn's procedure (two-tailed test). $\mathrm{CIT}=$ citric acid infusion; $\mathrm{EW}=$ enzyme infusion followed by water dip; $\mathrm{EC}=$ enzyme infusion followed by citric acid dip; $\mathrm{WW}$ = water infusion followed by water dip; $\mathrm{WC}=$ water infusion followed by citric acid dip.

Table 2. Firmness of 'Valencia' and 'Hamlin' orange slices, and pH, titratable acidity (TA), and soluble solids content (SSC) of the juice during storage at $5{ }^{\circ} \mathrm{C} .{ }^{\mathrm{z}}$

\begin{tabular}{|c|c|c|c|c|c|}
\hline $\begin{array}{l}\text { Storage } \\
\text { (days) }\end{array}$ & Treatment & Firmness $(\mathrm{N})$ & TA (\% citric acid $)$ & $\mathrm{pH}$ & $\mathrm{SSC}\left({ }^{\circ} \mathrm{Brix}\right)$ \\
\hline & & & encia’' & & \\
\hline \multirow[t]{5}{*}{1} & CIT & $46.6 \mathrm{a}$ & $0.494 \mathrm{a}$ & $4.43 \mathrm{~b}$ & $10.8 \mathrm{a}$ \\
\hline & EW & $33.4 \mathrm{~b}$ & $0.428 \mathrm{bc}$ & $4.41 \mathrm{~b}$ & $10.1 \mathrm{~b}$ \\
\hline & EC & $32.6 \mathrm{~b}$ & $0.415 \mathrm{~cd}$ & $4.41 \mathrm{bc}$ & $11.0 \mathrm{a}$ \\
\hline & WW & $46.2 \mathrm{a}$ & $0.379 \mathrm{~d}$ & $4.52 \mathrm{a}$ & $9.9 \mathrm{~b}$ \\
\hline & WC & $45.9 \mathrm{a}$ & $0.468 \mathrm{ab}$ & $4.32 \mathrm{c}$ & $9.8 \mathrm{~b}$ \\
\hline \multirow[t]{5}{*}{7} & CIT & $41.0 \mathrm{a}$ & $0.442 \mathrm{a}$ & $4.47 \mathrm{a}$ & $10.7 \mathrm{a}$ \\
\hline & EW & $27.2 \mathrm{~b}$ & $0.412 \mathrm{ab}$ & $4.39 \mathrm{~b}$ & $10.5 \mathrm{a}$ \\
\hline & EC & $25.2 \mathrm{~b}$ & $0.429 \mathrm{a}$ & $4.26 \mathrm{c}$ & $10.5 \mathrm{a}$ \\
\hline & WW & $40.3 \mathrm{a}$ & $0.381 \mathrm{~b}$ & $4.50 \mathrm{a}$ & $10.2 \mathrm{a}$ \\
\hline & WC & $42.2 \mathrm{a}$ & $0.440 \mathrm{a}$ & $4.37 \mathrm{~b}$ & $10.3 \mathrm{a}$ \\
\hline \multirow[t]{5}{*}{16} & CIT & $54.3 \mathrm{a}$ & $0.435 \mathrm{~b}$ & $4.58 \mathrm{~b}$ & $10.8 \mathrm{a}$ \\
\hline & EW & $24.3 \mathrm{~b}$ & $0.335 \mathrm{~d}$ & $4.51 \mathrm{c}$ & $10.3 \mathrm{~b}$ \\
\hline & EC & $27.2 \mathrm{~b}$ & $0.483 \mathrm{a}$ & $4.30 \mathrm{~d}$ & $10.9 \mathrm{a}$ \\
\hline & WW & $49.1 \mathrm{a}$ & $0.362 \mathrm{~d}$ & $4.69 \mathrm{a}$ & $10.0 \mathrm{bc}$ \\
\hline & WC & $47.4 \mathrm{a}$ & $0.398 \mathrm{c}$ & $4.59 \mathrm{~b}$ & $9.9 \mathrm{c}$ \\
\hline \multicolumn{6}{|c|}{ 'Hamlin' } \\
\hline \multirow[t]{5}{*}{1} & CIT & $33.1 \mathrm{a}$ & $0.852 \mathrm{a}$ & $3.80 \mathrm{a}$ & $11.3 \mathrm{a}$ \\
\hline & EW & $20.6 \mathrm{c}$ & $0.715 \mathrm{~b}$ & $3.83 \mathrm{a}$ & $10.6 \mathrm{bc}$ \\
\hline & $\mathrm{EC}$ & $19.7 \mathrm{c}$ & $0.812 \mathrm{a}$ & $3.74 \mathrm{~b}$ & $11.0 \mathrm{ab}$ \\
\hline & WW & $36.2 \mathrm{a}$ & $0.713 \mathrm{~b}$ & $3.81 \mathrm{a}$ & $10.4 \mathrm{c}$ \\
\hline & WC & $27.4 \mathrm{~b}$ & $0.792 \mathrm{a}$ & $3.72 \mathrm{~b}$ & $10.7 \mathrm{bc}$ \\
\hline \multirow[t]{5}{*}{7} & CIT & $34.9 \mathrm{a}$ & $0.713 \mathrm{ab}$ & $4.01 \mathrm{~b}$ & $11.0 \mathrm{a}$ \\
\hline & EW & $18.9 \mathrm{c}$ & $0.669 \mathrm{~b}$ & $3.94 \mathrm{bc}$ & $10.6 \mathrm{a}$ \\
\hline & $\mathrm{EC}$ & $15.9 \mathrm{c}$ & $0.745 \mathrm{ab}$ & $3.79 \mathrm{~d}$ & $10.4 \mathrm{a}$ \\
\hline & WW & $28.6 \mathrm{~b}$ & $0.525 \mathrm{c}$ & $4.15 \mathrm{a}$ & $10.3 \mathrm{a}$ \\
\hline & WC & $31.0 \mathrm{ab}$ & $0.746 \mathrm{a}$ & $3.87 \mathrm{~cd}$ & $10.4 \mathrm{a}$ \\
\hline \multirow[t]{5}{*}{14} & CIT & $31.1 \mathrm{a}$ & $0.661 \mathrm{ab}$ & $4.10 \mathrm{ab}$ & $10.9 \mathrm{a}$ \\
\hline & EW & $17.8 \mathrm{~b}$ & $0.583 \mathrm{~cd}$ & $4.06 \mathrm{ab}$ & $10.9 \mathrm{a}$ \\
\hline & $\mathrm{EC}$ & $19.8 \mathrm{~b}$ & $0.715 \mathrm{a}$ & $3.89 \mathrm{c}$ & $11.0 \mathrm{a}$ \\
\hline & WW & $32.0 \mathrm{a}$ & $0.544 \mathrm{~d}$ & $4.16 \mathrm{a}$ & $10.0 \mathrm{~b}$ \\
\hline & WC & $32.5 \mathrm{a}$ & $0.616 \mathrm{bc}$ & $4.04 \mathrm{~b}$ & $10.2 \mathrm{~b}$ \\
\hline \multirow[t]{5}{*}{21} & CIT & $27.4 \mathrm{a}$ & $0.581 \mathrm{ab}$ & $4.02 \mathrm{~b}$ & $11.5 \mathrm{a}$ \\
\hline & EW & $16.3 \mathrm{~b}$ & $0.581 \mathrm{ab}$ & $3.95 \mathrm{bc}$ & $11.0 \mathrm{~b}$ \\
\hline & $\mathrm{EC}$ & $16.0 \mathrm{~b}$ & $0.626 \mathrm{a}$ & $3.85 \mathrm{c}$ & $11.2 \mathrm{ab}$ \\
\hline & WW & $29.7 \mathrm{a}$ & $0.448 \mathrm{c}$ & $4.17 \mathrm{a}$ & $10.1 \mathrm{c}$ \\
\hline & WC & $31.2 \mathrm{a}$ & $0.536 \mathrm{~b}$ & $4.01 \mathrm{~b}$ & $10.4 \mathrm{c}$ \\
\hline
\end{tabular}

${ }^{2}$ Means followed by a different letter indicate significance difference between treatments within storage by the Duncan multiple range test, $\alpha=0.05$.

$\mathrm{CIT}=$ citric acid infusion; $\mathrm{EW}=$ enzyme infusion followed by water dip; $\mathrm{EC}=$ enzyme infusion followed by citric acid dip; $\mathrm{WW}=$ water infusion followed by water dip; $\mathrm{WC}=$ water infusion followed by citric acid dip. 
Titratable acidity, $p H$, and soluble solids content. Before testing firmness, the outer surface of the slices was measured for $\mathrm{pH}$ using indicator strips (color $\mathrm{pHas}^{\mathrm{TM}} \mathrm{EM}$ Science, Gibbstown, NJ). After firmness measurements, juice $\mathrm{pH}$ and TA were analyzed by taking a $10-\mathrm{mL}$ sample from each replication diluted with $50 \mathrm{~mL}$ double deionized water and titrated with $0.1 \mathrm{~N} \mathrm{NaOH}$ to a pH 8.1 end point using an Orion 950 titrator (Thermo Electron Corp., Beverly, MA). Total SSC was determined with two measurements for each replication with a digital ATAGO PR-101 refractometer (Atago Co., Ltd., Tokyo).

Volatile analysis. The headspace of juice from 'Hamlin' slices used in firmness testing was analyzed using an Agilent 6890N GC (Agilent Technologies, Santa Clara, CA) equipped with a $0.53 \mathrm{~mm} \times 30 \mathrm{~m}, 1.0-\mathrm{mm}$ film-thickness, polar Stabilwax column (Restek, Bellefonte, PA), a $0.53 \mathrm{~mm} \times$ $30 \mathrm{~m}, 1.5-\mathrm{mm}$ film-thickness nonpolar HP-5 column (Agilent Technologies), a flame ionization detector, and a Gerstel MPS2 autosampler (Gerstel, Baltimore, MD). Vials $(10 \mathrm{~mL})$ containing $3 \mathrm{~mL}$ of juice were heated to $40{ }^{\circ} \mathrm{C}$ for $15 \mathrm{~min}$ and then $2 \mathrm{~mL}$ of the headspace was injected in a splitless mode and partitioned between the two columns. The conditions of the run were: initial temperature $40{ }^{\circ} \mathrm{C}$ for $6 \mathrm{~min}$, then to $180{ }^{\circ} \mathrm{C}$ at $6^{\circ} \mathrm{C}$ per min and held at $180^{\circ} \mathrm{C}$ for $1.67 \mathrm{~min}$, and then to $240{ }^{\circ} \mathrm{C}$ at $50^{\circ} \mathrm{C}$ per min. Injector and detector temperatures were $250{ }^{\circ} \mathrm{C}$. Volatiles were quantified using calibration curves obtained from deodorized orange juice in which volatiles are removed by rotary evaporation and then spiked with five levels of standards (Sigma-Aldrich, St. Louis) (Baldwin et al., 1995).

Sensory analysis. A 20-member experienced panel (panel accustomed to evaluating citrus products) was instructed in a brief session on the ranking test procedure before the experiment. Panelists were asked to rank 'Valencia' oranges in a decreasing order of preference for "texture" and "flavor" attributes after $2 \mathrm{~d}$ and $8 \mathrm{~d}$ in storage. Samples, one slice per treatment, were presented with a three-digit code on the same plate in a randomized order.

For 'Hamlin' oranges, a 9-point hedonic scale $(1=$ "dislike extremely," $5=$ "neither like nor dislike," 9 = "like extremely") was used instead of a ranking test because, during the previous test with 'Valencia' oranges, panelists expressed difficulty in ranking all the samples from the five treatments in one sitting. "Appearance" was added to "texture" and "flavor" evaluations because it was considered a discriminative parameter among different treatments according to comments from 'Valencia' sensory tests. Samples, one slice per treatment, were presented as previously with a three-digit code in a randomized order.

Statistical analyses. Quality parameters (firmness, pH, TA, SSC, and volatiles) were analyzed by analysis of variance with the SAS statistical software (SAS System soft- ware v.9.1, 1999; SAS Institute, Cary, NC). Mean separation within each storage period was performed using the Duncan's multiple range test with $\alpha=0.05$. Volatile data were additionally examined using factor analysis using the principal component method on the data correlation matrix to account for differences in peak scaling (Johnson and Wichern, 1992; SAS, 1999). Microbial data $\left(\log \mathrm{cfu} \cdot \mathrm{g}^{-1}\right)$ were analyzed using the Kruskal-Wallis test, and multiple comparisons were performed with the Dunn's procedure using XL-Stats (Addinsoft, Paris, France). Ranked sensory data
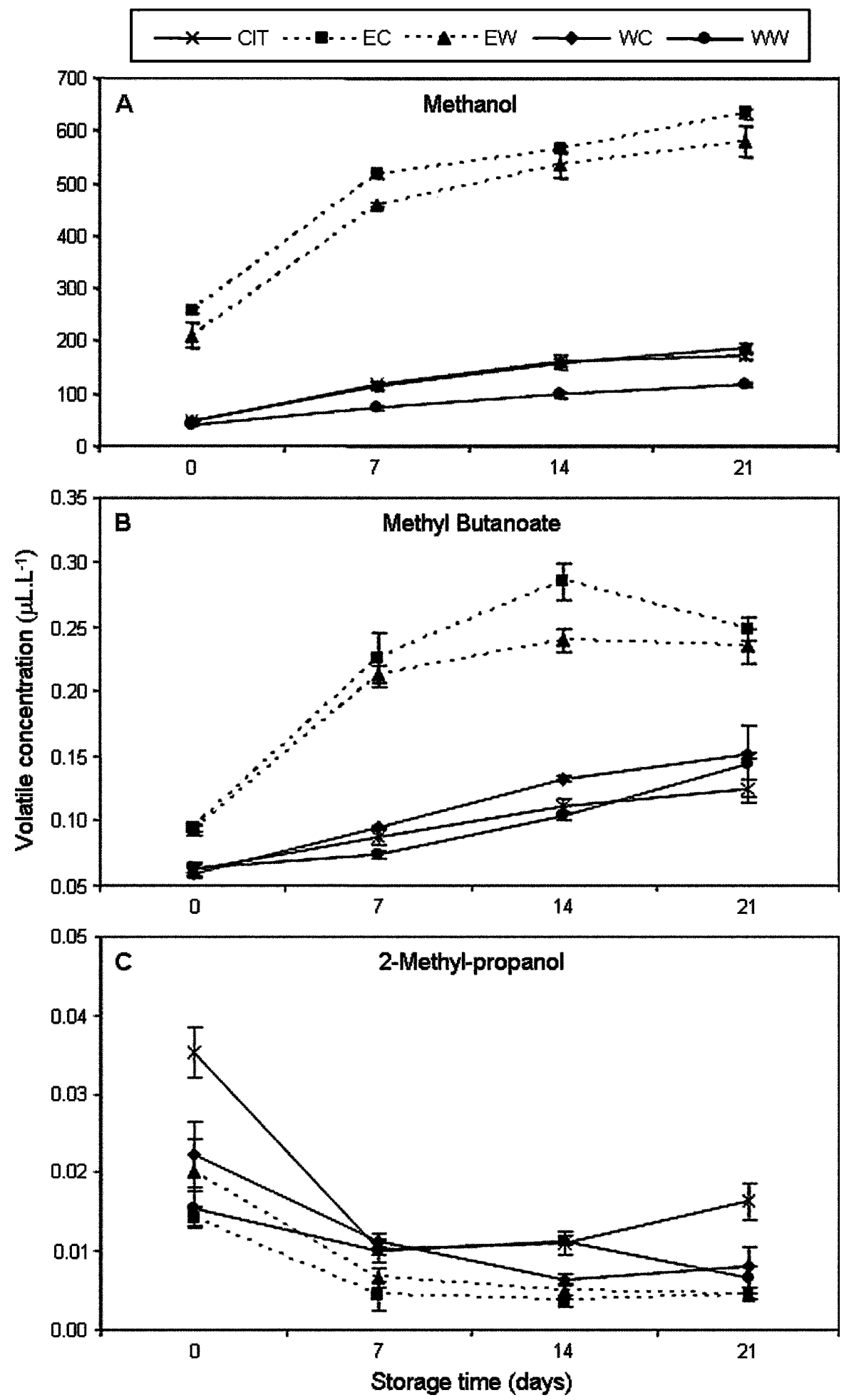

Fig. 1. Changes in (A) methanol, (B) methyl butanoate, and (C) 2-methyl propanol in fresh-cut 'Hamlin' oranges. Data are means of three values with standard error bars. CIT = citric acid infusion; EW = enzyme infusion followed by water dip; $\mathrm{EC}=$ enzyme infusion followed by citric acid dip; $\mathrm{WW}=$ water infusion followed by water dip; $\mathrm{WC}=$ water infusion followed by citric acid dip. 
were analyzed using the Friedman test (Meilgaard et al., 1999). Sensory scores obtained with the 9-point hedonic scale were analyzed using PROC GLM and mean scores separation was done using the Duncan's multiple range test with $\alpha=0.05$ (SAS, 1999).

\section{Results and Discussion}

Fruit microbiological stability. All 'Valencia' samples had microbial counts less than $1.0 \mathrm{cfu} \cdot \mathrm{g}^{-1}$ throughout the first week of storage. After 2 weeks, only slices from water-infused fruit followed or not by a CA dip (WW or WC) had 4.40 and $2.75 \mathrm{log}$ cfu. ${ }^{-1}$, respectively (Table 1 ). After $21 \mathrm{~d}$, the total count on slices from water-infused fruit was similar; slices from enzymatic infusion had 2.13 and $3.71 \log \mathrm{cfu} \cdot \mathrm{g}^{-1}$ without and with additional CA dip (EW and EC), respectively, whereas samples infused in citric acid under vacuum still had less than $1.0 \mathrm{cfu} \cdot \mathrm{g}^{-1}$. For 'Hamlin' initially, only slices from enzyme and water infusion not followed by a CA dip (EW and WW) had microbial counts greater than $1.0 \mathrm{cfu} \cdot \mathrm{g}^{-1}(2.34$ and 2.50 $\log \mathrm{cfu} \cdot \mathrm{g}^{-1}$, respectively; Table 1). Dipping slices in CA reduced microbial counts on both fruit that were water- or enzyme-infused (WC and EC), except on day 14 for WC. On day 14, WC had a short-term spike of microbial count most probably the result of an open niche for growth of sublethal cells at that one point in time. Total counts generally remained lower throughout storage on enzyme-infused than water-infused slices not dipped in CA (not significant on day 14). Slices from CA-infused whole fruit maintained very low counts (less than 1.3 $\log \mathrm{cfu} \cdot \mathrm{g}^{-1}$ ) throughout storage. In summary, for both cultivars, effectiveness of CA for reducing microbial counts was greater when used in the infusion bath, rather than as a postpeeling dip, especially for 'Valencia', in agreement with earlier work by Pao and Petracek (1997). In the present experiment, infusion or postpeeling treatment with $1 \%$ citric acid solution $(\mathrm{pH}=2.30)$ reduced surface $\mathrm{pH}$ from 5.0 to 5.5 to $\approx 3.0$ to 3.5 , which would explain growth suppression of fast-growing spoilage bacteria (Pao and Petracek, 1997). The maximum microbiological shelf life of peeled oranges was defined as the time required to reach an aerobic plate count of $5.0 \mathrm{log} \mathrm{cfu} \cdot \mathrm{g}^{-1}$ (Pao et al., 1996b). In this experiment, microbial counts never reached that value, confirming the effectiveness of sanitizing fruit with PAA before cutting (Narciso and Plotto, 2005).

\section{Fruit quality}

Firmness. The use of enzyme for peeling oranges resulted in softer slices in both cultivars (EW and EC) for all storage durations (Table 2). When comparing across storage, 'Valencia' slices from enzymeinfused oranges continued to lose firmness during storage, whereas water- or CAinfused fruit (WW, WC, and CIT) did not change significantly during 2 weeks (46 N initially to $49 \mathrm{~N}$ for WW) (statistical significance not shown). Slices from CA-infused fruit (CIT) had higher firmness at the end of storage $(54.3 \mathrm{~N})$, probably as a result of the dehydration of the surface albedo. For 'Hamlin', firmness did not change significantly during storage. As a varietal trait,
'Hamlin' oranges were in general softer than 'Valencia' fruit, which tend to be more fibrous.

Titratable acidity, $\mathrm{pH}$, and soluble solids content. For 'Valencia', a CA infusion of whole oranges (CIT) generally resulted in higher TA compared with water- or enzymeinfused fruit with no postpeeling CA dip
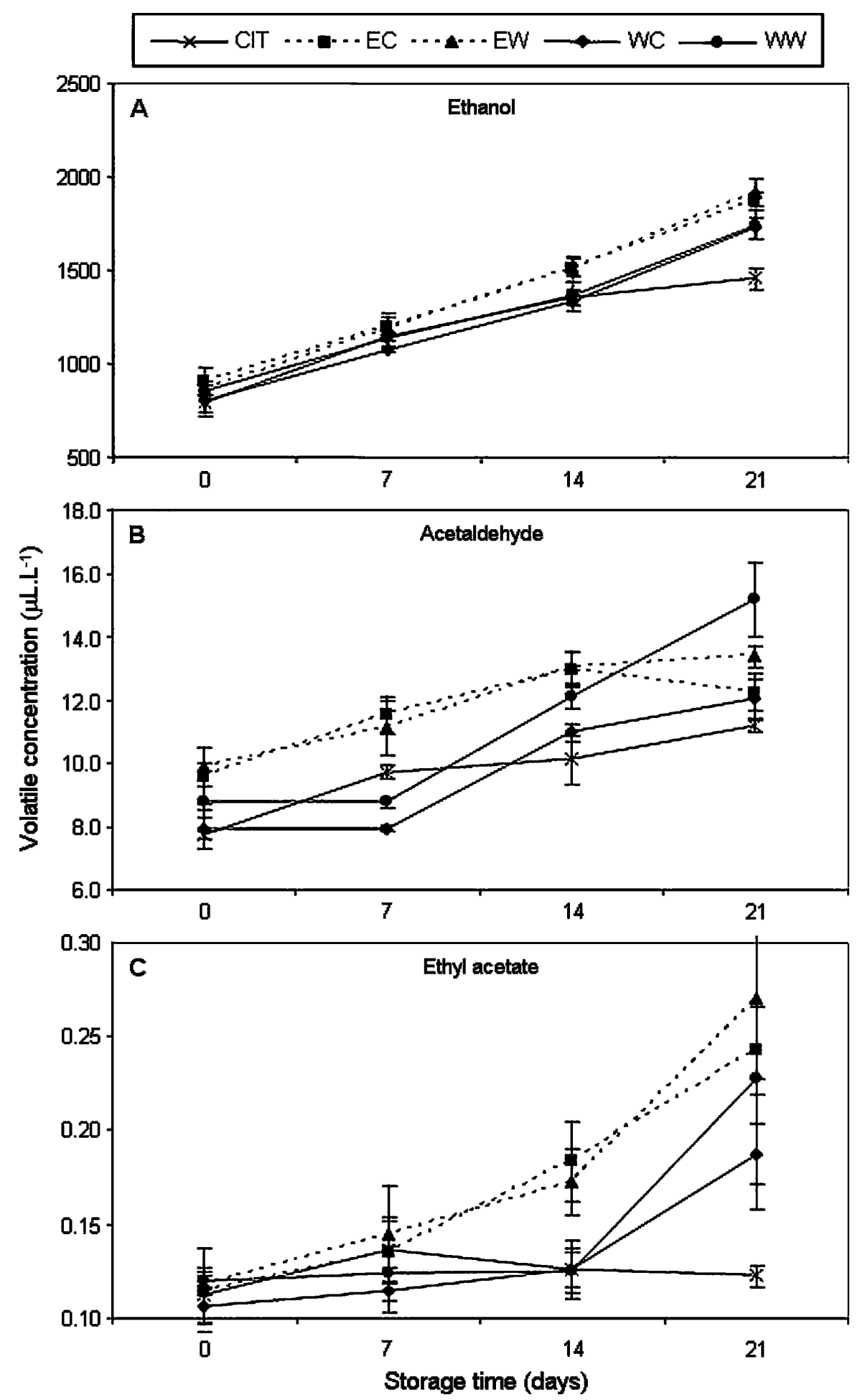

Fig. 2. Changes in (A) ethanol, (B) acetaldehyde, and (C) ethyl acetate in fresh-cut 'Hamlin' oranges. Data are means of three values with standard error bars. CIT = citric acid infusion; EW = enzyme infusion followed by water dip; $\mathrm{EC}=$ enzyme infusion followed by citric acid dip; $\mathrm{WW}=$ water infusion followed by water dip; $\mathrm{WC}=$ water infusion followed by citric acid dip. 
(WW or EW) (Table 2); CA dips of slices after cutting resulted in higher TA for waterinfused slices initially and in storage (WW versus WC) and only after $16 \mathrm{~d}$ for enzymeinfused slices (EW versus EC). For 'Hamlin', $\mathrm{CA}$ used in the infusing solution or on cut slices increased TA initially (CIT, EC, or WC); higher TA was maintained in storage, but not always significantly. Independent of treatments, TA gradually decreased during storage $(5 \%$ to $21 \%$ and $12 \%$ to $24 \%$ decrease after $14 \mathrm{~d}$ for 'Valencia' and 'Hamlin', respectively), except for 'Valencia' slices dipped in CA after enzymatic infusion (EC) and the ones treated with water (WW), for which TA remained low throughout storage. Unlike TA, $\mathrm{pH}$ was not significantly influenced by citric acid, and over 2 weeks of storage, $\mathrm{pH}$ increased for all treatments, except for 'Valencia' slices dipped in CA after enzymatic infusion (EC). Soluble solids content was higher for oranges vacuum infused with CA (CIT) and with enzyme followed by a CA dip (EC), initially, for both cultivars, and after $16 \mathrm{~d}$ for 'Valencia' and $21 \mathrm{~d}$ for 'Hamlin'. Higher SSC may be from residual citric acid as well as electrolyte leakage resulting from residual enzyme activity in enzyme-peeled fruit, because SSC measures not only soluble sugars, but also any soluble material, including acids and soluble pectins.

Volatiles. Slices from fruit that had been enzyme-infused had significantly higher methanol and methyl butanoate production than fruit not treated with pectinase (Fig. 1). Pectinase products contain pectinmethylesterase activity that releases methyl groups from pectin, thus exposing demethylated regions, which are substrates for polygalacturonase (Daas et al., 1998). Methanol is found in the headspace of tomato tissue that has been macerated or homogenized as a result of pectin degradation (Baldwin et al., 2000). The higher level of methyl butanoate indicates a substrate specificity of 'Hamlin' alcohol acyl transferase (or ester synthase) to butanoic acid and excess methanol in enzyme-peeled oranges (Ueda et al., 1992). On the other hand, the level of 2-methylpropanol was not higher for enzyme-peeled fruit than other treatments, confirming the most possible precursor of this branched alcohol to be an amino acid such as $L$-isoleucine (Hansen and Poll, 1993; Rowan et al., 1996). Fermentative metabolites, ethanol, acetaldehyde, and ethyl acetate, generally increased in storage, except for slices from oranges vacuum-infused with CA (CIT), which had lower amounts of ethanol and ethyl acetate after $21 \mathrm{~d}$ (Fig. 2). Although there was no difference between treatments for ethanol, acetaldehyde was higher for enzyme-infused fruit after $7 \mathrm{~d}$ and ethyl acetate was higher after $14 \mathrm{~d}$. Hexanal, hexanol, trans-2-hexenol, and 2-methyl propanol were lower for EC fruit than either water- or CA-infused fruit, depending on storage (data not shown, except 2-methyl propanol; Fig. 1). Enzyme-infused fruit tended to have lower amounts of $\alpha$-pinene, $\gamma$-terpinene, myrcene, and limonene, especially after 14 and $21 \mathrm{~d}$ in storage (data not shown). There was no trend for linalool, $\alpha$-terpineol, terpinen-4-ol, and octanal. A factor analysis with Varimax rotation gives an overall picture of sample treatments and storage in the space determined by the vectors for each volatile component (Fig. 3 ). Generally, slices that were not enzymeinfused (WW or WC) or enzyme-infused at time 0 (EC0 or EW0) had positive scores for Factor 1 (explaining $43 \%$ of the variation) with high loading values for myrcene, limonene, ethyl-3-hydroxy hexanoate, hexanol, methylpropanol, $\gamma$-terpinene, $\alpha$-pinene, and decanal volatiles. Slices that were enzymeinfused and stored 7 to $21 \mathrm{~d}$ had negative scores on Factor 1 (tended to be higher in methyl butanoate, methanol, and the fermentative volatiles). The volatiles characterizing the positive side of Factor 1 are usually known to be contributors of orange juice flavor (Moshonas and Shaw, 1994; Shaw, 1991), whereas those characterizing the negative side of Factor 1 reflected the high amount of methanol and methyl butanoate in enzyme-peeled fruit (already discussed previously) and also tended to be associated with fermentative conditions, often associated with aging fruit. Factor 2 explained $11 \%$ of the variation, and cis-3-hexenol and octanal had higher loadings on the positive side, with mostly samples from enzyme-infused oranges and CA-infused samples stored 0 to $7 \mathrm{~d}$ (CIT 0,7), whereas the negative side of Factor 2 was characterized by hexanal, and samples that were water- or CA-infused and stored 14 or $21 \mathrm{~d}$. In summary, the slices from enzyme-peeled fruit, when stored, generally showed reduced levels of many important citrus flavor volatiles with the exception of methyl butanoate and octanal while exhibiting elevated levels of fermentative volatiles and methanol. Methanol threshold in water is 740 ppm (w/v) (Amoore and Hautala, 1983); it is therefore very likely to be much higher in an orange matrix resulting from volatilematrix interactions (Plotto et al., 2004a) and is not likely to have any direct effect on flavor, except modifying the volatility of other volatile components, which in itself could modify flavor perception of enzymetreated slices. Acetaldehyde, ethyl acetate, and octanal concentrations were much lower in 'Hamlin' than their odor thresholds in an orange juice matrix (Plotto et al., 2004a, 2004b) and therefore these compounds are not expected to have any effect on flavor differences between treated slices. Likewise, ethanol concentration is higher than ethanol threshold, but there were no statistical differences between treatments for ethanol alone (Fig. 1). On the other hand, the range of methyl butanoate for enzyme-peeled slices was 212 to $285 \mathrm{ppb}$, twice the level found for odor and taste thresholds when tested in deodorized orange juice (Plotto et al., 2004b). The higher level of methyl butanoate in enzyme-peeled slices is therefore likely to be perceived as fruitier when eating these orange slices.

Sensory evaluation. For 'Valencia' oranges, texture of slices from enzymeinfused fruit was preferred in comparison with those from water and citric acid infusion (Fig. 4). Differences between sample texture preferences were greater after $8 \mathrm{~d}$ of storage, when enzyme-peeled slices were softer, and preferred to water- or CA-infused slices. On the other hand, texture of slices from water and CA infusion was not perceived positively as a result of the toughness of membranes and

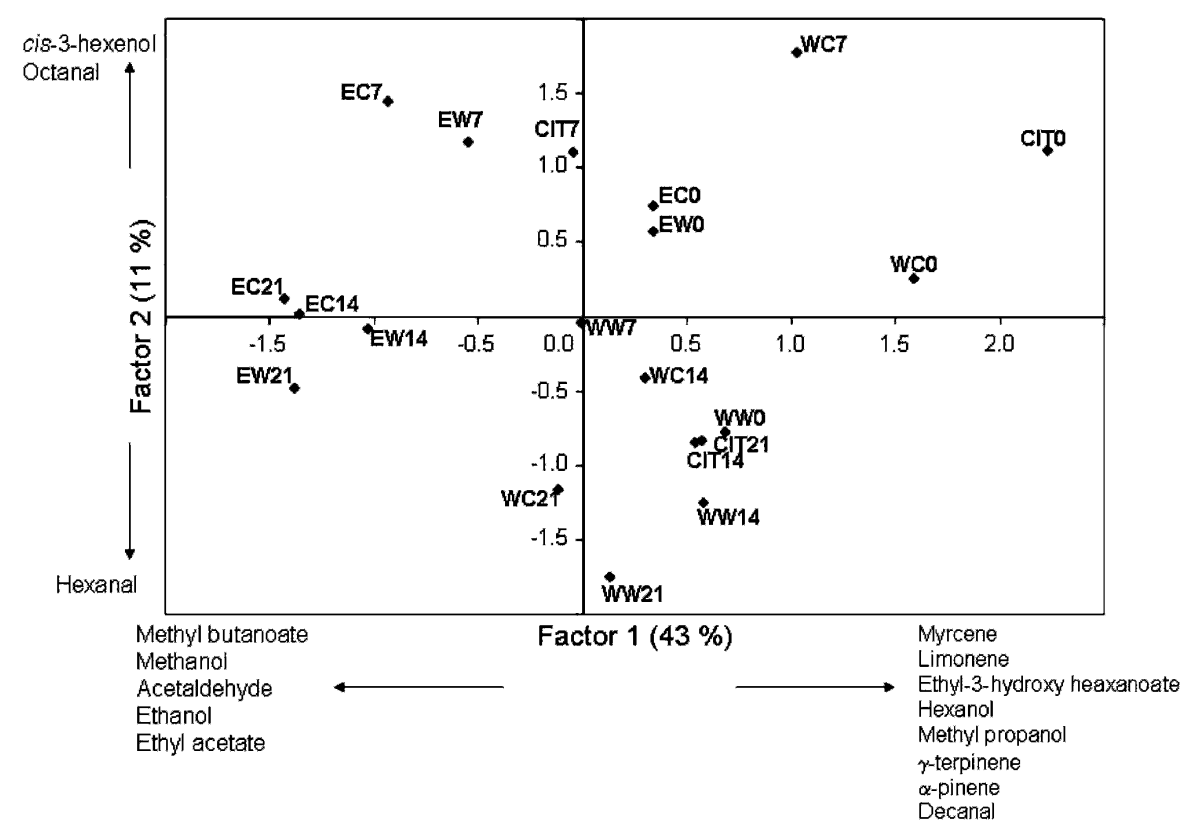

Fig. 3. Factor analysis of volatile compounds. $\mathrm{CIT}=$ citric acid infusion; $\mathrm{EW}=$ enzyme infusion followed by water dip; $\mathrm{EC}=$ enzyme infusion followed by citric acid dip; $\mathrm{WW}=$ water infusion followed by water dip; WC $=$ water infusion followed by citric acid dip. The number after the treatment code indicates days in storage at $5{ }^{\circ} \mathrm{C}$. 
the dryness of albedo and were more difficult to chew. For 'Hamlin', appearance of slices from enzyme-infused fruit was preferred and given higher ratings initially and up to 2 weeks of storage (Fig. 5). These slices appeared smooth and shiny as a result of the absence of albedo, whereas slices both from water and CA infusion were dull, dry-looking, and slightly whitish in color as a result of adhering albedo tissue. When eating the slices, average preference for texture was not different between treatments despite differences in firmness measured instrumentally. This was the result of a difference in opinions between panelists either preferring or disliking the softer slices from enzyme peeling. The use of citric acid as a postpeeling treatment of slices had no influence on appearance or texture preference for either cultivar. No differences among treatments were reported for flavor throughout storage for either 'Valencia' or 'Hamlin' orange slices despite the differences in volatile profiles. A trained panel might more easily detect flavor differences in enzyme-peeled slices resulting from higher methyl butanoate.

Citric acid can be used as a complement to fresh-cut sanitation, provided the fruit is properly sanitized before cutting. Citric acid was more effective when used in the infusion solution as previously reported by Pao and

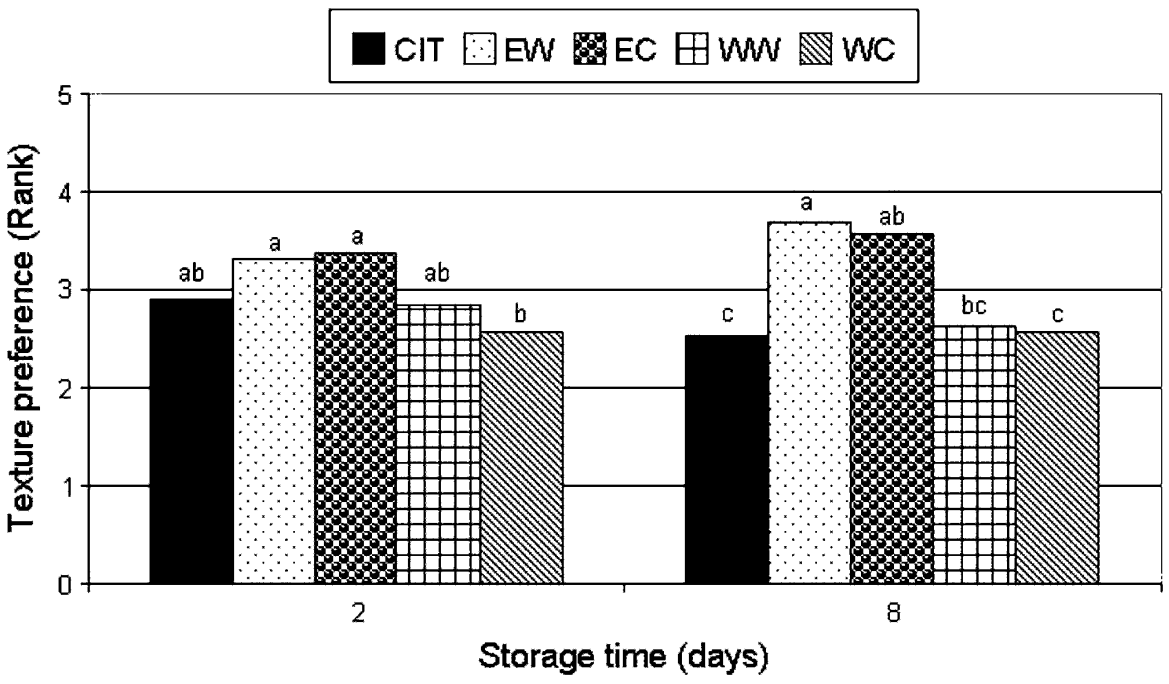

Fig. 4. Texture ranking by order of decreasing preference for 'Valencia' oranges. Bars with different letters indicate significant difference between treatments by the Friedman test $(\alpha=0.05)$. CIT $=$ citric acid infusion; $\mathrm{EW}=$ enzyme infusion followed by water dip; $\mathrm{EC}=$ enzyme infusion followed by citric acid dip; $\mathrm{WW}=$ water infusion followed by water dip; $\mathrm{WC}=$ water infusion followed by citric acid dip.

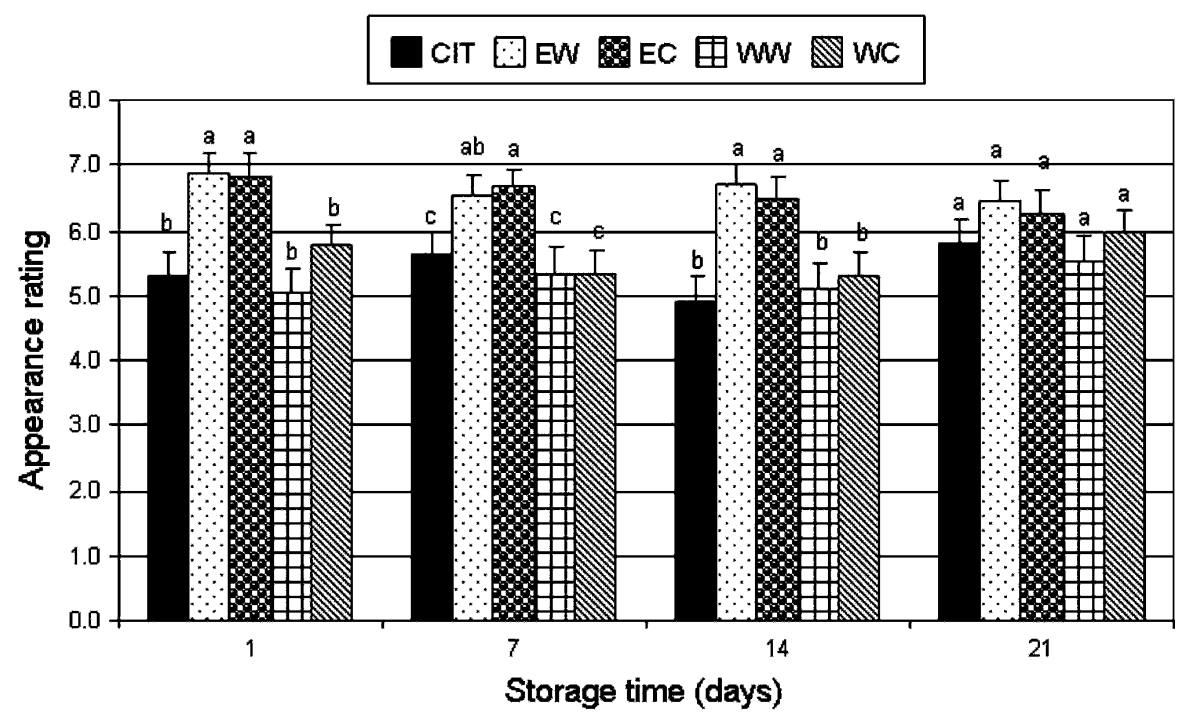

Fig. 5. Appearance liking for 'Hamlin' oranges. The 9-point hedonic scale was used. Bars with different letters indicate significance difference between treatments by the Duncan multiple range test, $\alpha=0.05$. $\mathrm{CIT}=$ citric acid infusion; $\mathrm{EW}=$ enzyme infusion followed by water dip; $\mathrm{EC}=$ enzyme infusion followed by citric acid dip; $\mathrm{WW}=$ water infusion followed by water $\mathrm{dip} ; \mathrm{WC}=$ water infusion followed by citric acid dip.
Petracek (1997). The slight increase in TA of CA-infused oranges did not affect flavor preference in either 'Valencia' or 'Hamlin' slices. The use of enzyme-assisted peeling resulted in fruit with preferred texture for 'Valencia' but not for 'Hamlin'. However, enzyme peeling resulted in slices with preferred appearance for 'Hamlin'. This is in contrast to another study with 'Moro' oranges, in which enzyme-peeled oranges were least preferred for texture and flavor (Pinnavaia et al., unpublished data) showing that the effect of enzyme on orange slices can be cultivar-dependent. Enzyme peeling efficiency and resulting fruit quality were also shown to vary with growing conditions (seasonal variation) (Ismail et al., 2005). The effect of enzyme peeling on orange volatiles has never been shown before, and although flavor differences were not perceived in this study, it is possible that the change in volatile profile could be more pronounced with longer storage or in other cultivars.

\section{Literature Cited}

Abeles, F.B. 1973. Ethylene in plant biology. Academic Press, New York.

Amoore, J.E. and E. Hautala. 1983. Odor as an aid to chemical safety: Odor thresholds compared with threshold limit values and volatilities for 214 industrial chemicals in air and water dilution. J. Appl. Toxicol. 3:272-290.

Baker, R.A. and J.H. Bruemmer. 1989. Quality and stability of enzymically peeled and sectioned citrus fruit, p. 140-148. In: J. Jen (ed.). Quality factors of fruits and vegetables: Chemistry and technology. ACS Symposium Series 405, American Chemical Society, Washington, DC.

Baker, R.A. and R.D. Hagenmaier. 1995. Edible coatings to reduce fluid loss of minimally processed grapefruit, p. 107. 1995 IFT Annual Meeting: Book Abstracts (abstr.).

Baldwin, E.A., M.O. Nisperos, P.E. Shaw, and J.K. Burns. 1995. Effect of coatings and prolonged storage conditions on fresh orange flavor volatiles, degrees brix, and ascorbic acid levels. J. Agr. Food Chem. 43:1321-1331.

Baldwin, E.A., J.W. Scott, C.K. Shewmaker, and W. Schuch. 2000. Flavor trivia and tomato aroma: Biochemistry and possible mechanisms for control of important aroma components. HortScience 35:1013-1022.

Bruemmer, J.H. 1981. Method for preparing citrus fruit with fresh fruit flavor and appearance. U.S. Patent 4,284,651.

Cooperhouse, H.L. 2003. Innovations in fruit technology. Fresh cut magazine, Feb. 2003.

Daas, P.J.H., P.W. Aritsz, H.A. Schols, G.A. De Ruitter, and A.G.J. Voragen. 1998. Analysis of partially methyl-esterified galacturonic acid oligomers by high-performance anionexchange chromatography and matrix-assisted laser desorption/ionization time-of-flight mass spectrometry. Anal. Biochem. 257:195-202.

Florida Department of Citrus (FDOC). 2006 8 Dec. 2006. $<\mathrm{http} / / \mathrm{www}$.Floridajuice.com/ nutrition_fresh_facts.php>.

Hansen, K.L. and L. Poll. 1993. Conversion of $L$-isoleucine into 2-methyl-2-enyl esters in apples. Lebensm.-. Wiss. Technol. 26:178180 .

Hobbs, G. 1986. Ecology of food microorganisms. Microbiol. Ecol. 12:15-30.

Hodge, K. 2003. Market trends bode well for freshcut, p. 30-31. Fresh Cut, Oct. 2003. 
Ismail, M., H. Chen, E.A. Baldwin, and A. Plotto. 2005. Changes in enzyme-assisted peeling efficiency and quality of fresh 'Valencia' orange and of stored 'Valencia' orange and 'Ruby Red' grapefruit. Proc. Fla. State Hort. Soc. 118:403-405.

Johnson, R.A. and D.W. Wichern. 1992. Applied Multivariate Statistical Analysis. 3rd ed. Prentice Hall, Englewood Cliff, NJ.

Meilgaard, M., G.V. Civille, and B.T. Carr. 1999. Sensory Evaluation Techniques. 3rd ed. CRC Press, Boca Raton, FL.

Moshonas, M.G. and P.E. Shaw. 1994. Quantitative determination of 46 volatile constituents in fresh, unpasteurized orange juices using dynamic headspace gas chromatography. J. Agr. Food Chem. 42:1525-1528.

Narciso, J.A. and A. Plotto. 2005. A comparison of sanitation systems for whole fruit and fresh-cut mango. Hort Technology 15:1-6.

Pao, S. and P.D. Petracek. 1997. Shelf life extension of peeled oranges by citric acid treatment. Food Microbiol. 14:485-491.

Pao, S.C., P.D. Petracek, and G.E. Brown. 1996a. Nonenzymatic fruit peeling method. U.S. Patent 5,560,951.

Pao, S., P.D. Petracek, and G.E. Brown. 1996b. Effect of infusion method on peel removal and storage quality of citrus. HortTechnology 6:409-413.

Pao, S., W.W. Widmer, and P.D. Petracek. 1997. Effects of cutting on juice leakage, microbio- logical stability and bitter substances of peeled citrus. Lebensm.-Wiss. U-Technol. 30:670675.

Pinnavaia, S., E.A. Baldwin, A. Plotto, J.A. Narciso, and E. Senesi. 2006. Enzyme-peeling of Valencia oranges for fresh-cut slices. Proc. Fla. State Hort. Soc. 119:335-339.

Plotto, A., C.A. Margaría, K.L. Goodner, R. Goodrich, and E.A. Baldwin. 2004a. Odour and flavour thresholds for key aroma components in an orange juice matrix: Terpenes and aldehydes. Flavour Fragrance J. 19:491498.

Plotto, A., C.A. Margaría, K.L. Goodner, and E.A. Baldwin. 2004b. Threshold values for key aroma components in an orange juice matrix: Esters, p. 70. 2004 IFT Annual Meeting Technical Program Abstracts. Abstract 33B-5.

Pretel, M.T., P. Lozano, F. Riquelme, and F. Romojaro. 1997. Pectic enzymes in fresh fruit processing optimization of enzymic peeling of oranges. Process Biochem. 32:43-49.

Rocha, A.M.C.N., C.M. Brochardo, R. Kirby, and A.M.M.B. Morais. 1995. Shelf-life of chilled cut orange determined by sensory quality. Food Contr. 6:317-322.

Rowan, D.D., H.P. Lane, J.M. Allens, S. Fiedler, and M.B. Hunt. 1996. Biosynthesis of 2methylbutyl, 2-methyl-2-butenyl, and 2-methylbutanoate esters in Red Delicious and Granny Smith apples using deuterium-labeled substrates. J. Agr. Food Chem. 44:32763285 .

SAS. 1999. SAS system software version 9.1. SAS Institute, Cary, NC.

Senesi, E., A. Calabretto, and G. Toso. 2003. Arance di IV gamma: Indagine preliminare sulle operazioni di preparazione. Frutticoltura 3:49-54.

Senesi, E., S. Pinnavaia, M. La Prova, and A. Calabretto. 2005. Arance pronte per il consumo. L'Informatore Agrario 4:73-75.

Shaw, P.E. 1991. Fruits II, p. 305-327. In: H Maarse (ed.). Volatile compounds in foods and beverages. Marcel Dekker, New York.

Ueda, Y., A. Tsuda, J. Bai, N. Fujishita, and K. Chachin. 1992. Characteristic pattern of aroma ester formation from banana, melon and strawberry with reference to the substrate specificity of ester synthetase and alcohol contents in pulp. J. Japan. Soc. Food Sci. Technol. 39: 183-187.

Warren, K. 2006. Fresh-cut trends, p. 6. Fresh Cut, the magazine for value-added produce. Oct. 2006 .

Zhuang, H., M.M. Barth, and T.R. Hankionson. 2003. Microbial safety, quality and sensory aspects of fresh-cut fruits and vegetables, p. 255-278. In: J.S. Novak, G.M. Sapers, and V.K. Junega (eds.). Microbial safety of minimally processed foods. CRC Press, Boca Raton, FL. 